\title{
Themed Section of Impacting Education Focused on CPED's Principle
}

\author{
Jill A. Perry, PhD \\ University of Pittsburgh \\ Executive Director CPED \\ jill.perry@cpedinitiative.org \\ Debby Zambo, PhD \\ Associate Director CPED \\ debby.zambo@cpedinitiative.org
}

This themed section of Impacting Education (IE) focuses on the use of the Carnegie Project on the Education Doctorate's (CPED) Guiding Principles for EdD program design. Authors in this section are CPED Writing Fellows who have been selected because of their experience around engaging the Principles in their program design. To become a Fellow each author posed a manuscript around the theme, created a draft version, and came together at the June 2017 convening to align their work with others, provide constructive feedback, and form support groups to ensure manuscript completion and acceptance. The following articles in this section are the result of this year-long process.

Focusing on CPED's Guiding Principles for Program Design offers readers of IE an understanding of the foundation of CPED's Framework (to access these go to https://www.cpedinitiative.org/page/AboutUs) which over 100 schools of education have now used to redesign their EdD programs. These Principles were created in a collaborative effort of member faculty (Perry, 2016; Perry, Zambo, \& Wunder, 2015) to move the Consortium away from a prescriptive EdD program model, toward a more flexible framework that would make professional practice preparation in education as purposeful, fluid, and meaningful as possible The result of this work was not only the Guiding Principles for Program Design but also a movement that has made CPED the first action-oriented effort working to distinguish and define the EdD as a rigorous and relevant degree for professional practice (Perry, 2010, 2012; Perry \& Imig, 2008). In this themed section, manuscripts written by Writing Fellows show the impact of the principles on their EdD programs. To help readers get a grounding into the importance of this work, we provide background into the development of the principles.

\section{WHY GUIDING PRINCIPLES?}

In 2006, Shulman, Golde, Beuschel and Garabedian suggested, "The extent to which the professional practice doctorate requires a new vision demands a 'zero-base' approach to design, without any of the assumptions that characterize the status quo" (p. 28). This idea supported the creation of the Carnegie Project on the Education Doctorate (CPED) and provided the challenge to begin afresh and create a program model that would be adopted across all institutions, much like program models in medical or legal professional preparation. At the June 2009 convening, however, CPED faculty expressed strong opposition to a "one-size fits all" program prescription. They claimed programs needed to honor local contexts by supporting the unique preparation needs of regions and the unique circumstances of each university setting. However, all agreed that to advance the $\mathrm{EdD}$ as a strong and rigorous professional degree, a measure of commonality and quality needed to exist across institutions. Together, these members concluded that the development of a set of principles to characterize excellent doctoral preparation would be the best way to support program development across a diverse set of institutions.

During the June 2009 convening, a conversation ensued and several statements specific to one of CPED's design concepts (e.g., capstones, signature pedagogies, labs of practice) or to a particularly promising practice, say, admissions (e.g., "expert practitioners should sit on the admissions committee") were generated. While it was not surprising that initial conversations were focused on smaller program design elements, members eventually saw the need for a broader level discussion. The discussion that ensued focused on developing principles that might govern an entire program (e.g., "build a broad experience base") rather than a particular practice attached to a particular way of admitting students, proposing capstones, selecting laboratories of practice, etc.

Development of a set of guiding principles was agreed upon but because the consortium at the time was comprised of three groups: institutions working on programs for those seeking to practice school leadership, those focused on teacher education, and those focused on institutional leadership/higher education, more questions were raised as to if the principles should be specific to program areas or broadly applied to the EdD in general. After more discussion, it was concluded that as members worked within their own institutions, their program areas and institutional contexts should certainly influence what was being designed, implemented, and tested. At the conclusion of this discussion, members saw the need to think across areas of concentration.

New articles in this journal are licensed under a Creative Commons Attribution 4.0 United States License.

This journal is published by the University Library System of the University of Pittsburgh as part of its D-Scribe Digital Publishing Program and is cosponsored by the University of Pittsburgh Press.

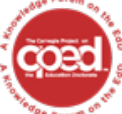

This journal is supported by the Carnegie Project on the Education Doctorate: A Knowledge Forum on the EdD (CPED) cpedinitiative.org

ISSN 2472-5889 (online) DOI 10.5195/ie.2018.89 
A final point focused on was the purpose of the principles. In June 2009, members used the terms "Principles of Best Practice" and "Principles of Practice", but the "practice" to which the participants were referring was the practice related to the implementation of a doctoral program designed to prepare educational practitioners. The term "practice" did not refer to specific practices of professional educators. For that reason, it was proposed that the membership employ a more precise label for the principles.

\section{DEVELOPMENT OF THE GUIDING PRINCIPLES}

As a result of an analysis of "The June 2009 Convening Principle Discussion," members were asked to bring to the October 2009 convening a set of principles or ideas that guided their home institution EdD program development. Specifically, members were asked to bring broad statements of principles that would apply to any doctoral program seeking to prepare educational practitioners. After removal of repetitive statements, 35 statements served as the basis for the work. Over the course of the three days of the convening, 49 faculty participants representing 24 of the original 25 -member institutions worked with the 35 statements that ranged in applicability from specific elements of a program to the EdD in general. As members worked, they knew that the resulting CPED principles would be aimed at, and judged against, the following criterion: Preparing doctoral students who graduate with the potential to transform the professional practice of education. Wanting to lessen the number of statements, members were first divided into five groups and asked to narrow them using the following criteria. Statements should:

1. cut across all areas of the program-from capstone to courses, and

2. clearly demonstrate why this program is an EdD and not a PhD.

Statements that did not meet these criteria were removed. Next, the groups identified overarching themes that were represented across the remaining statements. The five groups then combined and narrowed statements into the following themes:

1. Social justice and equity

2. Inquiry related to problems of practice

3. Collaboration

4. Multi-disciplinary

5. Stewardship

Statements were then narrowed again utilizing these themes. Remaining statements were sorted under the themes resulting in 10 principles. Those ten were handed to a subgroup of members who narrowed and word-smithed the list to the current six principles.

However, the principles were not the only idea emerging. During this same timeframe, a definition for the EdD surfaced from discussions around the principles. Together, the work of the October 2009 convening-a new definition of the EdD and a set of guiding principles for program design - became the core foundation for the future work of CPED. These state:

We, the members of CPED believe:

"The professional doctorate in education prepares educators for the application of appropriate and specific practices, the generation of new knowledge, and for the stewardship of the profession."

With this understanding, we have identified the following statements that will focus a research and development agenda to test, refine, and validate principles for the professional doctorate in education.

The Professional Doctorate in Education:

1. Is framed around questions of equity, ethics, and social justice to bring about solutions to complex problems of practice.

2. Prepares leaders who can construct and apply knowledge to make a positive difference in the lives of individuals, families, organizations, and communities.

3. Provides opportunities for candidates to develop and demonstrate collaboration and communication skills to work with diverse communities and to build partnerships.

4. Provides field-based opportunities to analyze problems of practice and use multiple frames to develop meaningful solutions.

5. Is grounded in and develops a professional knowledge base that integrates both practical and research knowledge, that links theory with systemic and systematic inquiry.

6. Emphasizes the generation, transformation and use of professional knowledge and practice (CPED, 2009).

These principles were to be adopted and applied to member programs with the hope that their implementation would create better programs and, in the future, allow CPED to secure funding to investigate if, and how, the principles changed and improved CPED-influenced EdD programs.

\section{STUDYING THE IMPACT OF THE PRINCIPLES}

In 2010, CPED received a $\$ 700,000$ U.S. Department of Education Fund for the Improvement of Post-secondary Education (FIPSE) grant to study how 21 of its original member schools of education changed their EdDs. Specifically, the research project sought to use a multicase analysis to: 
1. Document and evaluate change in the organizational structures of graduate schools to accommodate new professional practice degrees for school and college leaders.

2. Document and evaluate change in the signature learning processes, learning environments, and patterns of engagement of faculty and candidates in EdD programs that participate in CPED.

3. Document and evaluate fidelity to the set of program principles developed in the first three years of the initiative (2007-2009).

4. Disseminate lessons learned and best practices for the design and implementation of professional practice degrees to a new cohort of graduate schools of education.

A cross-case analysis of 21 cases, conducted and written by 38 CPED faculty researchers, revealed the following claims and evidence about the how original CPED member institutions were working with the principles. In 2015, Perry, Zambo \& Wunder reported findings from the full project. Below is an overview of the areas that pertain to the principles.

\section{Incorporating the Principles}

At the outset of the study, the researchers (Perry, Zambo, \& Wunder, 2015) looked to see if CPED's principles were being incorporated into $\mathrm{EdD}$ designs. From their analysis, they learned that the principles were being incorporated in all 21 programs, but in varying time frames, ways, and with levels of understanding. Faculty and deans interviewed at 12 institutions $(57 \%)$ claimed their programs were based on principle-like ideas and established before, or independent of, development of the principles. This is understandable because the principles were developed as a result of the experimenting with program designs during Phase I of the project. Even as ideas were being developed, institutions were redesigning their programs. However, even though some programs had been developed with facets of the principles, seven institutions $(33 \%)$ said they were using the principles in their current design/redesign of their process.

Next, the researchers wanted to understand how the principles were being implemented. Participants from two institutions (9\%) said incorporation of the principles was not consciously done, while participants from four institutions (19\%) said that incorporation of the principles was achieved through negotiation, dialogue and collegiality. This included having a strong change agent (faculty member) who worked thoughtfully and consciously to incorporate CPED's principles, goals, and design features into their programs. In these cases, faculty met multiple times per year and negotiated ways to infuse CPED principles into their programs. Participants from three institutions (14\%) said CPED's philosophy as articulated in the principles aligned with their own beliefs and this contributed to the ease of incorporating them into their program design and curriculum development. Alternatively, participants from four other institutions (19\%) said there were challenges incorporating the principles. Challenges included perceptions that more could be done, a wanting of a more formal adoption process, and a lack of cohesion as to how different departments talked about and used the principles.

Additionally, cases revealed that CPED principles influenced programmatic information and depending on where a program was in the design/implementation process, this information was used in different ways. Forty-eight percent of participants interviewed said the CPED principles were most useful in the development of courses and curriculum. Whereas, another $24 \%$ of participants stated the principles were useful in the creation of a cohort-based EdD model even though there is no mention of cohorts in the principles. Specifically, participants at 18 institutions $(86 \%)$ said the principles were used to benchmark their programs. These members used the principles to determine if their redesign efforts were aligned with CPED's vision. To do this, they looked at how the principles were incorporated into their program's outcomes, courses, assignments, syllabi, research, dissertations, cohorts, and learning communities. These same participants noted that the principles were conducive to developing programs based on students' needs. The CPED Principles helped faculty:

Program Design

- $\quad$ use students' workplaces as their laboratories of practice

- $\quad$ require a capstone focused on a problem of practice

- integrate practical and research knowledge (theory and practice)

- employ a cohort program model to foster collaboration

- $\quad$ emphasize transformation in student thinking to see the bigger picture

- $\quad$ create embedded internships

Teaching

- $\quad$ honor the scholarship of teaching

- encourage critical thinking among their students about topics of importance like social justice

- $\quad$ require cycles of inquiry

- $\quad$ support students in finding solutions to problems of practice

- $\quad$ enhance student communication skills by using technology and class presentations

- focus on how knowledge is constructed and the application of knowledge to make a positive difference in people's lives

- be attentive to the needs of adult learners

Overall, this early investigation helped CPED understand how its member institutions were beginning to utilize the principles in their EdD program designs. This learning revealed that the principles were the foundation for CPED's work and because of this, helped shape future convenings and support new members as they joined. 


\section{UNDERSTANDING MORE ABOUT THE PRINCIPLES}

In 2017, CPED launched a major data collection effort across 86 of its members to understand more about what CPED-influenced member programs look like and how the CPED Framework had influenced these institutions, their programs, and the individuals involved with them. As part of this effort, questions were specifically asked about the how the guiding principles were enacted. Data were gathered through an online, open- and closed-ended survey that was completed by the primary faculty contact (known as the principal investigator) for each member institution. Our research questions pertaining to the guiding principles were:

1. How are CPED's principles prominent in program design?

2. How are CPED's principles prominent in pedagogy?

3. How are CPED's principles prominent in graduate outcomes?

At this early stage of analysis, 22 of the 86 surveys (26\%) have been analyzed and show that the principles have made an impact on these three areas. Below is a summary of early findings.

\section{Preliminary Findings}

Research question \#1: Program Design. Data from this collection effort show that the principles are being used in program design and redesign efforts with commonalities and differences. At many institutions, mission and vision statements contain ideas and terminology from various principles which are used to design EdD programs, their curriculum, and coursework. Various principles also affect how students are admitted (cohorts) into programs, where they perform their work (in laboratories of practice), the type of dissertations they write, and the support they receive. CPED-influenced programs are not clones of each other, however. Members use and interpret the principles based on their particular contexts and students' needs locally. Table 1 contains the ways each of the principles is prominent in program design.

Table 1. The Guiding Principles implemented in EdD Program Design

\begin{tabular}{|c|c|}
\hline Principle & Ways Prominent in Program Design \\
\hline $\begin{array}{l}1 \text { - Is framed around questions of equity, ethics, and social justice to } \\
\text { bring about solutions to complex problems of practice. }\end{array}$ & $\begin{array}{l}\text { Mission statements focused on equity, ethics, and social justice. } \\
\text { Mission statements translated into courses and what students learn. } \\
\text { Courses focused on developing leaders who work for empowerment and conduct research ethically. } \\
\text { Dissertations in Practice focused on empowerment, improvement, and change. }\end{array}$ \\
\hline $\begin{array}{l}2 \text { - Prepares leaders who can construct and apply knowledge to make a } \\
\text { positive difference in the lives of individuals, families, organizations, and } \\
\text { communities. }\end{array}$ & $\begin{array}{l}\text { Mission statements focused on making a difference. } \\
\text { Cohorts provided development and support. } \\
\text { Selective and varied research/dissertation work useful to practice and aimed at developing leaders who apply } \\
\text { literature/research, develop changes, and evaluate the effects of this work on families, organizations, and } \\
\text { communities. }\end{array}$ \\
\hline $\begin{array}{l}3 \text { - Provides opportunities for candidates to develop and demonstrate } \\
\text { collaboration and communication skills to work with diverse } \\
\text { communities and to build partnerships. }\end{array}$ & $\begin{array}{l}\text { Mission statements focused on collaboration, communication, and partnerships. } \\
\text { Curriculum (core and research courses) employ internships and field experiences for applied learning. } \\
\text { Courses and dissertations required students to form partnerships and build communication. }\end{array}$ \\
\hline $\begin{array}{l}4 \text { - Provides field-based opportunities to analyze problems of practice } \\
\text { and use multiple frames to develop meaningful solutions. }\end{array}$ & $\begin{array}{l}\text { Mission statements focused on field-based opportunities and the use of multiple frames. } \\
\text { Courses are selective and varied. } \\
\text { Cohorts provide support. } \\
\text { Dissertations used multiple frames to find meaningful solutions. }\end{array}$ \\
\hline $\begin{array}{l}5 \text { - Is grounded in and develops a professional knowledge base that } \\
\text { integrates both practical and research knowledge, that links theory with } \\
\text { systemic and systematic inquiry. }\end{array}$ & $\begin{array}{l}\text { Mission statements focused on developing students' professional knowledge and helping them integrate it with } \\
\text { what they learn. } \\
\text { Coursework used students' knowledge and is contextualized in practice. } \\
\text { Courses delivered in ways that meet students' needs. }\end{array}$ \\
\hline $\begin{array}{l}6 \text { - Emphasizes the generation, transformation, and use of professional } \\
\text { knowledge and practice. }\end{array}$ & $\begin{array}{l}\text { Mission statements focused on knowledge generation. } \\
\text { Courses strived to develop students' professional knowledge and leadership capabilities } \\
\text { Coursework is contextualized in laboratories of practice. } \\
\text { Dissertations focused on impact, transformation, and the generation of knowledge for practice. }\end{array}$ \\
\hline
\end{tabular}

Research question \#2: Pedagogy. In terms of pedagogy, data show commonalities and variation in use of the principles. Commonalities demonstrate the principles are used to develop pedagogy that is based on students' needs as adult learners, contextualized in practice, and focused on problems of practice. Differences show varied delivery systems, work, and interaction patterns. The principles are influencing pedagogy but being adapted based on faculty's interpretation. Table 2 contains the ways each of the principles play out in program pedagogy. 
Table 2. The Principles in Pedagogy

\begin{tabular}{|c|c|}
\hline Principle & Ways Prominent in Pedagogy \\
\hline $\begin{array}{l}1 \text { - Is framed around questions of equity, ethics, and social justice to bring } \\
\text { about solutions to complex problems of practice. }\end{array}$ & $\begin{array}{l}\text { Lectures, seminars, discussions, speakers and fieldwork focused on social justice. } \\
\text { Cooperative and problem-based learning, cycles of research, critical analysis, and constructive feedback are } \\
\text { used. }\end{array}$ \\
\hline $\begin{array}{l}2 \text { - Prepares leaders who can construct and apply knowledge to make a } \\
\text { positive difference in the lives of individuals, families, organizations, and } \\
\text { communities. }\end{array}$ & $\begin{array}{l}\text { Lectures, dialogue, and speakers. } \\
\text { Experiential and collaborative learning. } \\
\text { Civic engagement projects and fieldwork are used to apply what is learned. }\end{array}$ \\
\hline $\begin{array}{l}3 \text { - Provides opportunities for candidates to develop and demonstrate } \\
\text { collaboration and communication skills to work with diverse communities } \\
\text { and to build partnerships. }\end{array}$ & $\begin{array}{l}\text { Lectures, discussions, speakers, questioning, story-telling, and presentations. } \\
\text { Experiential and cooperative work, and fieldwork used. } \\
\text { Students interact and communicate with varied leaders. } \\
\text { Instructional teams model collaboration and ensure consistency. }\end{array}$ \\
\hline $\begin{array}{l}4 \text { - Provides field-based opportunities to analyze problems of practice and } \\
\text { use multiple frames to develop meaningful solutions. }\end{array}$ & $\begin{array}{l}\text { Face-to-face, online, in classrooms and in laboratories of practice during the week and on weekends. } \\
\text { Project based, design-based, collaborative, individual, and group focused. } \\
\text { Scaffolds learning. } \\
\text { Applicable and useable for the field. }\end{array}$ \\
\hline $\begin{array}{l}5 \text { - Is grounded in and develops a professional knowledge base that } \\
\text { integrates both practical and research knowledge, that links theory with } \\
\text { systemic and systematic inquiry. }\end{array}$ & $\begin{array}{l}\text { Use of case analysis, dialog about theory and practice. } \\
\text { Modeling and support/scaffolding } \\
\text { Having students conduct action-oriented incremental (cyclical), systematic research in the field. }\end{array}$ \\
\hline $\begin{array}{l}6 \text { - Emphasizes the generation, transformation, and use of professional } \\
\text { knowledge and practice. }\end{array}$ & $\begin{array}{l}\text { Lectures, speakers, seminars, discussions, and fieldwork. } \\
\text { Used small and large-group work, analysis of cases, self-assessments/reflection, hands-on-learning, } \\
\text { application of emerging technologies, and conflict resolution. } \\
\text { Students reflect on themselves as leaders. }\end{array}$ \\
\hline
\end{tabular}

Research question \#3: Graduate Outcomes. The principles are prominent in graduate outcomes at various levels (program, courses, assignments, assessments, dissertations) and varied ways. The data indicate that the principles are evident when graduates act as stewards of the profession by thinking systematically, creatively, and reflectively. In this sense, the graduate is now blending their professional knowledge with what they learned in their program, communicating more actively with a scholarly voice, taking on new professional responsibilities, and demonstrating career progression as a result of their program. In these ways, the principles are influencing who graduates become, however this looks different by region and need. Table 3 captures these ideas.

\section{Table 3. The Principles in Graduate Outcomes}

\begin{tabular}{|c|c|}
\hline Principle & Ways Prominent in Graduate Outcomes \\
\hline $\begin{array}{l}1 \text { - Is framed around questions of equity, ethics, and social justice to bring } \\
\text { about solutions to complex problems of practice. }\end{array}$ & $\begin{array}{l}\text { Graduates apply theories and conduct inquiry/research focused on policies and practices aimed at equity, ethics, } \\
\text { and social justice. } \\
\text { Change/impact their contexts through awareness, advocacy, action, stewardship, and leadership aimed at } \\
\text { equitable change/improvement. } \\
\text { Take on new professional responsibilities and demonstrate career progression. }\end{array}$ \\
\hline $\begin{array}{l}2 \text { - Prepares leaders who can construct and apply knowledge to make a } \\
\text { positive difference in the lives of individuals, families, organizations, and } \\
\text { communities. }\end{array}$ & $\begin{array}{l}\text { Graduates influence local and global contexts. } \\
\text { Generate evidence-based knowledge. } \\
\text { Build partnerships. } \\
\text { Act as stewards. } \\
\text { Commit to their professional development. } \\
\text { Share what they know. }\end{array}$ \\
\hline $\begin{array}{l}3 \text { - Provides opportunities for candidates to develop and demonstrate } \\
\text { collaboration and communication skills to work with diverse communities } \\
\text { and to build partnerships. }\end{array}$ & $\begin{array}{l}\text { Graduates network and build collaborative partnerships with diverse individuals. } \\
\text { Build and expand partnerships formed during dissertation work. } \\
\text { Communicate with a scholarly voice in varied ways and to varied individuals. } \\
\text { Continue to solve problems of practice. }\end{array}$ \\
\hline $\begin{array}{l}4 \text { - Provides field-based opportunities to analyze problems of practice and } \\
\text { use multiple frames to develop meaningful solutions. }\end{array}$ & $\begin{array}{l}\text { Graduates assess and use varied theories and to understand problems and design solutions. } \\
\text { Think systematically. } \\
\text { Value decision-making drawn from multiple sources. }\end{array}$ \\
\hline $\begin{array}{l}5-\text { Is grounded in and develops a professional knowledge base that } \\
\text { integrates both practical and research knowledge, that links theory with } \\
\text { systemic and systematic inquiry. }\end{array}$ & $\begin{array}{l}\text { Graduates use their professional knowledge to analyze and critique policies, theory, and research. } \\
\text { Consumers scholarship wisely. } \\
\text { Use their professional knowledge and what they learn to tackle problems of practice. } \\
\text { Reflect on how theory, research, and experience influence their leadership. }\end{array}$ \\
\hline $\begin{array}{l}6 \text { - Emphasizes the generation, transformation, and use of professional } \\
\text { knowledge and practice. }\end{array}$ & $\begin{array}{l}\text { Graduates act as scholarly practitioners - leaders who think and act with curiosity, inquiry skills, and scholarly } \\
\text { competencies, articulate how theory and research has influenced and built their professional knowledge and } \\
\text { leadership capabilities, apply evidence to decision making, and use creativity to problem-solve and transform } \\
\text { settings. }\end{array}$ \\
\hline
\end{tabular}


These preliminary finding show that the principles are intertwined in varied ways into program design, pedagogy, and graduate outcomes. But they also show that their use is difficult to capture holistically. Early findings are informative, but findings are presented with caution as there is more data to analyze.

\section{THE PRINCIPLES IN ACTION}

Development of the Guiding Principles was collaborative and since their creation, they have become the foundation for CPED's Framework which includes a new definition of the EdD, the six guiding principles, and six design concepts. As CPED has grown over the last 11 years, its members have investigated the use of the principles in program design, pedagogy, and graduate outcomes. These investigations have shown that the principles are being utilized in many ways within the consortium and at individual member institutions. Within the consortium, the guiding principles have provided the basis for CPED activities. For example, CPED committees have utilized the principles for developing criteria for the dissertation in practice and program of the year awards.

As research and information gathering, current efforts reveal the principles are also being used at member institutions in multiple ways. In program design, they are used to establish the goals of EdD programs. CPED's design concepts compliment the principles and serve as building blocks for the content of programs or as an evaluation tool for established programs. These facts make CPED the first action-oriented effort working to distinguish and define the $\mathrm{EdD}$ as a rigorous and relevant degree for professional practice. But the work is not over.

The goal of this themed section is to learn more deeply from several member institutions the ways in which the CPED Guiding Principles are serving its members' EdD programs. In the first article, Problems of Practice as Stance, Edmund 'Ted' Hamann and Guy Trainin openly, and honestly, describe a steadily changing, teacher leadership-oriented, CPED-affiliated EdD program housed in a department of curriculum and instruction at the University of Nebraska-Lincoln. The authors situate the program design in relation to four key concepts-epistemology, praxis, efficacy, and iterative processes and highlight CPED's core stance that the voice of the professional practitioner needs to be inserted into discussion of educational change, not as the target of policy, nor the object of research, but as a coequal partner in a research/policy/ practice triad in which practitioner insights related to context are key for the viability of educational efforts. The authors report the challenges of their change efforts (e.g., committee members, fixed beliefs) as well as their work to develop their program based on students' voices and needs.

The next article, Getting to Maybe: Improving the Education Doctorate in an Era of Uncertainty by Harriett Rasmussen, illuminates the evolutionary nature of knowledge in our society and the volatile, uncertain, complex, and ambiguous world and argues that because of these, graduate degrees play a critical role our future. In her article, Rasmussen argues that our current era of fake news and increasing disdain for academically based assertions places higher education directly in the eye of the current political storm. To her, success of doctoral programs, like the $\mathrm{EdD}$, depends on moving thorny problems of practice into their center and developing leaders who use what they learn to work for social injustice.

To realize this vision, Rasmussen suggests EdD programs be redesigned with CPED's principles and a complexity lens focused squarely on problems of practice and cycles of inquiry. The principles guide all aspects of programs, problems bridge the university-practice gap, and cycles help students understand the complexity of real world problems. The manuscript contains several visuals to help the reader understand ideas like these (complex systems, inquiry cycles, and organizational structures that influence and nurture change). This manuscript offers hope for higher education if it will situate its work in the reality of complex systems. This to Rasmussen will make a better world.

In the third article, Redesigning the Education Doctorate for Community College Leaders: Generation, Transformation, and Use of Professional Knowledge and Practice, Bartlett, Bartlett, Dolfi, Jaeger and Chapman describe the development of a community college executive EdD program at North Carolina State University. Specifically, the article focuses on guiding principle number six and explains how their program prepares leaders for "the generation, transformation, and use of professional knowledge and practice." The article is focused on the first three courses of the program's curriculum and how they were innated in the first year the program was offered. To provide understanding and continuous improvement of the program, the article beings in the voice of their students to understand their perspective on the impact of integrating this principle.

In the fourth article, Facilitating and Supporting EdD Students' Scholar Practitioner Writing as an Epistemological Tool, Carl Fertman describes the efforts being made at the University of Pittsburgh to develop scholarly writers. Fertman places writing at the center of student development and explains how EdD programs that utilize CPED's principles encourage writing that is original, transformative, and significant because it is framed around questions of equity, ethics, and social justice and explains efforts students take to affect the lives of individuals, families, organizations, and communities. In other words, writing, at the University of Pittsburgh, is used as a means to develop scholarly thinkers and the SQUIRE (Standards for Quality Improvement Reporting Excellence) guidelines and TIDieR (Template for Intervention Description and Replication Checklist and Guide) are used as quality standards for the scaffold, the Applied Inquiry Plan (AIP) they have developed as a programmatic pathway to guide a Dissertation in Practice. The manuscript explains the parts of the AIP and provides insight faculty need to recognize, consider, and do to develop writers.

In the fifth article, How CPED Guiding Principles and Design Concepts Influenced the Development and Implementation of an EdD Program, Buss takes an all-encompassing approach demonstrating how the principles have influenced all aspects of the Arizona State University EdD. Buss presents the global impact the principles have had on the core aspects of the program-the development of scholarly and influential practitioners, action research, and learner scholar communities as signature pedagogies. Buss also describes how the principles have supported the enactment of these three aspects through the curriculum and learning products of the students. The result, he explains, is a program that is continually improved to be more coherent and practitioner-oriented. 
In the final article, Program Innovation and Design in an Era of Accountability: EdD Faculty Work as Community of Practice, Philips, Geller, and Mawritz discuss how their program faculty worked as a learning community to conduct a crosswalk of their program principles, the CPED guiding principles and other national and university standards as they prepared for an accreditation process. The process offers an example of how faculty can engage the principles as a means of program assessment and continuous improvement.

\section{CLOSING THOUGHTS}

The authors of each of these pieces are actively engaged in the work of their EdD programs and deeply committed to the preparation of practitioners. They demonstrate how the CPED guiding principles have allowed their programs to evolve into professional practice doctorates while meeting the local needs of their institution and student populations. Our hope in presenting this sampling is to inform a broader community of how CPED can serve as a tool for both "reclaiming" (Shulman et al., 2006) the EdD and continuously improving it so that it serves the needs of those who lead our education systems.

\section{REFERENCES}

Carnegie Project on the Education Doctorate. (2009). Working principles for the professional practice doctorate in education. College Park, MD: Author.

Perry, J. A. (Ed.) (2015). The EdD and scholarly practitioners: The CPED Path. Charlotte, NC: IAP.

Perry, J. A. (2010). Reclaiming the education doctorate: Three cases of processes and roles in institutional change (Doctoral dissertation). University of Maryland, College Park.

Perry, J. A. (2012). What history reveals about the education doctorate. In M. Macintyre Latta \& S. Wunder (Eds.), Placing practitioner knowledge at the center of teacher education: Rethinking the policies and practices of the education doctorate (pp. 51-72). Charlotte, NC: Information Age Publishing.

Perry, J. A., \& Imig, D. G. (2008). A stewardship of practice in education. Change, 40(6), 42-48.

Perry, J. A., Zambo, D. \& Wunder, S. (2015). Understanding how Schools of Education have redesigned the Doctorate of Education. Journal of School Public Relations, 36, 58-85

Shulman, L. S., Golde, C. M., Bueschel, A. C., \& Garabedian, K. J. (2006). Reclaiming education's doctorates: A critique and a proposal. Educational Researcher, 35(3), 25-32. 